\title{
Pengembangan Usaha Kecil Studi pada Bank Syariah Mandiri Area Jambi
}

\author{
Agustina Mutia \& Mawarni \\ Fakultas Ekonomi dan Bisnis Islam UIN Sulthan Thaha Saifuddin Jambi \\ email : igoet_mutia@yahoo.com
}

\begin{abstract}
Abstrak: Tulisan ini bertujuan mengkaji kontribusi Bank Syariah Mandiri (BSM) Area Jambi dalam melakukan pengembangan usaha mikro, kecil dan menengah (UMKM). BSM Area Jambi suah berperan aktif bagi pengembangan UMKM di Kota Jambi dengan membantu pertumbuhan dan perkembangan usaha UMKM. Sebelumnya BSM berfokus pada pemberian modal usaha saja. Namun saat ini, BSM Area Jambi berperan dalam memberikan pendampingan usaha seperti mendorong izin usaha bagi usaha yang belum memiliki izin resmi dari pemerintah. Faktor yang mendukung kontribusi BSM dalam pembiayaan UMKM di Kota Jambi adalah agama penganut mendukung UMKM memilih pembiayaan BSM dan kebijakan pemerintah dalam bentuk KUR sebagai pembiayaan yang meringankan bagi UMKM. Sedangkan penghambatnya dari sisi nasabah adalah kesulitan menilai UMKM yang feasible dan bankable yang memenuhi persyaratan bank, akses informasi yang terbatasi kepada UMKM mengenai fasilitas pembiayaan yang ada, menyebabkan rendah animo masyarakat terhadap fasilitas pembiayaan BSM dan kesulitan membina manajemen UMKM seperti pemisahan keuangan antara keuangan pribadi dengan usaha.

Kata-kata kunci: BankSyariah Mandiri,UMKM, Jambi.
\end{abstract}

\section{Pendahuluan}

Salah satu fungsi bank adalah menyalurkan dana kepada masyarakat yang membutuhkan dana. Kebutuhan dana oleh masyarakat akan lebih mudah diberikan oleh bank apabila, masyarakat yang memmbutuhkan dana dapat memenuhi semua persyaratan yang diberikan oleh bank. Menyalurkan dana merupakan aktivitas yang sangat penting bagi bank. Karena bank akan memperoleh pendapatan atas dana yang disalurkan. Pendapat tersebut dapat berupa pendapatan bunga untuk bank konvensional, dan bagi hasil atau lainnya untuk bank syariah. Pendapatan yang diperoleh dari aktivitas penyaluran dana kepada nasabah merupakan pendapatan yang terbesar di setiap bank, sehingga penyaluran dana kepada masyarakat menjadi sangat penting bagi bank. ${ }^{1}$

Salah satu jenis bank di Indonesia yang menyalurkan dana kepada masyarakat adalah bank syariah. Jenis pembiayaan yang disalurkan di antaranya pembiayaan mudharabah. Pembiayaan mudharabah pembiayaan berakad jual beli adalah suatu perjanjian pembiayaan yang disepakati antara Bank Syariah dengan nasabah, dimana Bank Syariah menyediakan dananya untuk sebuah investasi dan atau pembelian barang modal dan usaha anggotanya kemudian proses pembayarannya dilakukan secara mencicil atau angsuran. Jumlah kewajiban yang

\footnotetext{
${ }^{1}$ Ismail, Manajemen Perbankan, (Jakarta: Kencana, 2013), hlm. 5.
} 
harus dibayarkan oleh peminjam adalah jumlah atas harga barang modal dan mark-up yang telah disepakati. ${ }^{2}$

UMKM merupakan usaha yang terdiri dari berbagai jenis yang masingmasing memiliki keterkaitan dalam proses pengeksploitasian ide atau kekayaan intelektual (intellectual property) menjadi nilai ekonomi tinggi yang dapat menciptakan kesejahteraan dan lapangan pekerjaan. ${ }^{3}$ UMKM yang memiliki implikasi yang cukup luas ketika mampu dimaksimalkan keberadaannya. Tidak hanya akan mampu menyerap tenaga kerja lebih banyak dibanding industri besar tetapi juga mampu menjadi salah untuk alat untuk mengentaskan kemiskinan. Meskipun volume perputaran barang dan jasa serta rupiah pada industri besar lebih tinggi dibanding UMKM, kenyataanya terjadi ketidakadilan dalam proses bagi hasil karena tentu pemilik industri besar akan memiliki porsi lebih banyak ketika mengalami keuntungan sebaliknya ketika mengalami kerugian akan berakibat pada pengurangan tenaga kerja. Sedangkan industri UMKM mampu lebih mandiri menjalankan kegiatan usahanya baik ketika mengalami keuntungan maupun kerugian. Dengan keadaan yang seperti itu, sangat dibutuhkan bantuan dari pihak lain berupa keuangan dari bank, di samping aspek manajemen dan teknologi untuk membangun UMKM yang tangguh.

Jumlah UMKM itu merupakan pasar yang sangat potensial bagi lembaga perbankan syari'ah untuk dijadikan mitra kerjasama. Oleh karena disamping kendala serius yang paling sering dihadapi oleh UMKM adalah permodalan, juga disisi lain joint venture (kerjasama kemitraan) adalah hubungan yang paling dibutuhkan oleh UMKM untuk mengembangkan usaha dan eksistensinya. Dalam konteks inilah keberadaan perbankan syari'ah dengan sistem kemitraan berbasis bagi hasil seharusnya menemukan relevansinya dengan jumlah UMKM yang cukup signifikan, apalagi dalam blue print pengembangan perbankan syari'ah, salah satu fungsi keberadaan perbankan syari'ah adalah membantu pengembangan UMKM, baik di tingkat nasional maupun di tataran lokal. ${ }^{4}$

Kondisi tersebut juga dialami oleh UMKM di Kota Jambi. Diharapkan, melalui pembiayaan yang diberikan oleh bank syariah dengan karakteristik yang berbeda dengan kredit/pinjaman (loan) dari bank konvensional, UMKM di Kota Jambi akan dapat memenuhi kebutuhan permodalan dimaksud.

Dari tabel di atas dapat dilihat bahwa UMKM mengalami perkembangan dari tahun 2012-2016 dan persentasenya selalu meningkat dari tahun 2012 hingga tahun 2016. Banyak banyak syariah yang menyalurkan pembiayaan untuk UMKM, maka salah satunya Bank Syariah Mandiri (BSM). BSM sebagai salah satu bank syariah yang sudah lama ada di Jambi sejak awal sudah memiliki komitmen untuk membantu usaha-usaha kecil ini melalui penyaluran pembiayaan. Hanya saja dalam perkembangannya penyaluran pembiayaan dari BSM tidak selalu berjalan normal atau meningkat, tetap ada naik turunnya,

Dari tabel di atas dapat dilihat bahwa UMKM mengalami perkembangan dari tahun 2013-2017, meskipun penyalurannya mengalami naik-turun. Di sisi

\footnotetext{
${ }^{2}$ Muhammad, Teknik Perhitungan Bagi Hasil dan Profit Margin pada Bank Syariah, (Yogyakarta: UII Press, 2006), hlm. 8.

${ }^{3}$ Ibid, hlm. 4.

${ }^{4}$ Eko Kurniasih Pratiwi \& Nasitotul Jannah, Peran Perbankan Syariah terhadap Pengembangan UMKM di Kota Magelang, (Jurnal FAI Universitas Muhammadiyah Magelang, 2014), hlm. 3.
} 
lain, Bank Syariah Mandiri atau BSM adalah salah satu bank syariah yang ada di Kota Jambi, yang biasa dikenal dengan slogan Lebih Adil dan Menenteramkan. BSM sendiri merupakan bank syariah terbesar di Indonesia memiliki portofolio hampir $70 \%$ adalah pembiayaan UMKM. Demikian juga dalam pembiayaan yang disalurkan BSM Area Jambi. BSM sebagai bank pemerintah bertanggung jawab dalam memajukan UMKM melalui penyaluran pembiayaan. Wawancara penulis dengan salah satu nasabah mengenai alasan memilih BSM sebagai intrumen pembiayaan bagi usahanya, maka berikut petikan wawancaranya: BSM sudah lama ada di Jambi dan produk-produknya sudah sesuai dengan keyakinan agama saya (Islam). Dengan demikian, maka saya nyaman bertransaksi di BSM." ${ }^{5}$

Berdasarkan pemaparan data, fakta, dan fenomena yang ada, penulis tertarik untuk meneliti lebih lanjut keikutsertaan perbankan syariah dalam meningkatkan UMKM melalui pembiayaan syariah. Berdasarkan latar belakang masalah yang penulis teliti maka rumusan masalah dalam penelitian ini adalah : Bagaimanakah kontribusi BSM Area Jambi dalam pengembangan UMKM di Kota Jambi, dan Apa sajakah faktor pendukung dan penghambat kontribusi BSM Area Jambi dalam pengembangan UMKM di Kota Jambi.

\section{Pengembangan Usaha Kecil Bank Syariah Mandiri}

Kontribusi adalah sumbangan atau pemberian atau kontribusi adalah pemberian andil setiap kegiatan, peranan, masukan, ide dan lainnya. ${ }^{6}$ Sedangkan Bank adalah lembaga keuangan yang usaha pokoknya memberikan pinjaman (kredit) dan jasa dalam pembayaran dan peredaran uang. ${ }^{7}$ Syariah adalah hukum agama yang menetapkan peraturan hidup manusia, hubungan manusia dng Allah SWT, hubungan manusia dengan manusia dan alam sekitar berdasarkan Al-Quran dan Hadis. ${ }^{8}$ Mekanisme kerja bank syariah adalah sebagai berikut. Bank syariah melakukan kegiatan pengumpulan dana dari nasabah melalui deposito/investasi maupun titipan giro dan tabungan. Dana yang terkumpul kemudian dinvestasikan pada dunia usaha melalui investasi sendiri (nonbagi hasil/trade financing) dan investasi dengan pihak lain (bagi hasil/investment financing). Ketika ada hasil (keuntungan), maka bagian keuntungan untuk bank dibagi kembali antara bank dan nasabah pendanaan. Di samping itu, bank syariah dapat memberikan berbagai jasa perbankan kepada nasabahnya. ${ }^{9}$

Bank Syariah adalah bank yang beroperasi sesuai dengan prinsip-prinsip syariah Islam dan dalam operasionalnya mengacu kepada ketentuan-ketentuan AlQur'an dan Al-Hadits. Yang dimaksud dengan prinsip-prinsip syariah di sini adalah ketentuan-ketentuan syariah Islam yang menyangkut tata-cara bermuamalah,

\footnotetext{
${ }^{5}$ Wawancara, 21 April 2017

${ }^{6}$ T. Guritno, Kamus Besar bahasa Indonesia dan Kamus Ekonomi, (Jakarta: 1992, Cet: II), hlm. 76.

${ }^{7}$ Anonim, Kamus Bahasa Indonesia, (Jakarta: Pusat Bahasa Departemen Pendidikan Nasional, 2008), hlm. 136.

${ }^{8}$ Ibid., hlm. 1402 .

${ }^{9}$ Ibid., hlm. 30.
} 
yaitu kegiatan yang menyangkut hubungan manusia dengan sesamanya dalam aspek sosial, ekonomi, politik dan budaya. ${ }^{10}$

Pada padal 1 ayat 7 Undang-undang Nomor 21 tahun 2008 tentang Perbankan Syariah menjelaskan bahwa bank syariah adalah bank yang menjalankan kegiatan usahanya berdasarkan prinsip syariah dan menurut jenisnya terdiri atas Bank Umum Syariah (BUS) dan Bank Pembiayaan Syariah (BPRS). Dalam menjalankan kegiatan usahanya, bank syariah dapat memberikan pembiayaan berdasarkan prinsip bagi hasil (mudāarabah), pembiayaan berdasarkan prinsip penyertaan modal (musyārakah), prinsip jual beli barang dengan memperoleh keuntungan (murābaḥah), atau pembiayaan barang modal berdasarkan prinsip sewa murni tanpa pilihan (ijārah), atau dengan adanya pilihan pemindahan kepemilikan atas barang yang disewa dari pihak bank oleh pihak lain (ijärah wa iqtina), akad salam, akad istisnä', sewa-menyewa yang diakhiri dengan kepemilikan (ijārah al-muntahiya bi tamlīk), dan lainnya yang tidak bertentangan dengan prinsip syariah. ${ }^{11}$

\section{Kontribusi BSM dalam Pengembangan UMKM di Kota Jambi}

Kontribusi BSM dalam membantu pengembangan UMKM, khususnya usaha kecil di Kota Jambi adalah:

\section{Menyalurkan Pembiayaan}

Upaya BSM Area Jambi dalam pengembangan usaha kecil yang ada dalam masyarakat kita dalam hal pemberian bantuan, BSM Area Jambi mengfokuskan prioritasnya kepada pemberian pembiayaan tidak didasarkan atas kedermawanan atau belas kasihan, sebab akan menyebabkan terjadinya ketergantungan pada pihak lain.

Perbankan syariah wajib melakukan penyaluran pembiayaan bagi umat Islam agar bisa membantu perkembangan ekonomi umat Islam. BSM Area Jambi sudah menjadi sumber alternatif pembiayaan bagi nasabah dengan diberikan modal pembiayaan, dengan memantau setiap perkembangan kegiatan nasabah pembiayaan termasuk mengadakan kunjungan kepada mereka yang memberikan peringatan dini jika terjadi penurunan kualitas pembiayaan yang dipekirakan mengandung risiko bagi bank. Wawancara dengan Andrialdi, Area Micro Banking Manager BSM Area Jambi bahwa: "Perbankan syariah selama ini sudah menjadi alternatif pembiayaan bagi masyarakat Jambi, termasuk umat Islam di Jambi" 12

Setiap tahun ada peningkatan dari total penyaluran dana tahun 2017 sebesar Rp. 19,425,000,000.00 ke berbagai level UMKM yang ada di Kota Jambi. Kemudian wawancara dengan Irman, nasabah BSM Area Jambi/pelaku UMKM bidang fotocopy yang beralamat di Jl. Arif Rahman Hakim Telanaipura Kota Jambi

\footnotetext{
${ }^{10}$ Hafidh Munawir, Perencanaan Strategi Pengembangan Bank Syariah di Indonesia, (Jurnal Ilmiah Teknik Industri Vol. 4 No. 1 Agustus 2005), hlm. 41.

${ }^{11}$ Pasal 19 Undang-undang Nomor 21 tahun 2008 tentang Perbankan Syariah

${ }^{12}$ Wawancara, Andrialdi, 26 Juli 2018
} 
bahwa: "Perbankan syariah selama ini sudah melakukan pengembangan usaha bagi saya di bidang fotocopy yaitu menambah alat-alat usaha dan karyawan." 13

Sebagai bank syariah yang sangat peduli terhadap pengembangan usaha kecil, Bank Syariah Mandiri (BSM) memiliki beragam produk untuk membantu pelaku UMKM. Salah satunya adalah BSM pembiayaan mikro. Sebagai Informasi dari Andrialdi, Area Micro Banking Manager BSM Area Jambi bahwa: "Pembiayaan mikro merupakan program kami yang ditujukan untuk membantu pengusaha UMKM, khususnya dalam penyediaan jaminan yang sesuai dengan kebutuhan usaha mikro.."14

Wawancara dengan Rini, nasabah BSM Area Jambi/pelaku usaha kecil Kelontong yang beralamat di Jl. Kapten Pattimura Kecamatan Alam Barajo Kota Jambi mengatakan bahwa: "BSM Area Jambi bagi saya sudah sangat membantu usaha saya di bidang industri rumah tangga, dan dengan modal yang disalurkan, saya bisa mengembangkan jaringan usaha yang ada dan meningkatkan kualitas produk usaha kecil saja. Untuk agunan saya penuhi dengan sertifikat rumah saja."15

Kontribusi BSM Area Jambi sebagai alternatif sumber pembiayaan sangat besar. Pemberdayaan ekonomi masyarakat oleh ini telah dijalankan oleh sebagian besar lembaga pembiayaan terutama lembaga pembiayaan seperti BSM Area Jambi. Wawancara dengan Andrialdi, Area Micro Banking Manager BSM Area Jambi mengatakan bahwa: "Saat ini kami mempunyai beberapa bidang usaha unggulan seperti usaha bengkel, pedagang pasar, toko kelontong, perdagangan sembako dan rumah makan, kesehatan/paramedis, dan lain-lain."16

Selain pembiayaan, Mandiri Syariah juga rutin memberikan pelatihan dan pendampingan usaha guna meningkatkan kompetensi usaha kecil. Menurut salah satu Rini, nasabah bahwa:

"Saya merasa sangat terbantu dengan adanya dukungan dari Mandiri Syariah seperti kunjungan usaha. Seiring dengan perkembangan usaha, saya mulai butuh dukungan modal. Tahun lalu saya mengenal BSM karena sistem syariahnya, proses cepat dan memuaskan. Sejak saat itu hingga sekarang saya nyaman dengan BSM. Saya adalah nasabah Mikro di bidang usaha home industry". ${ }^{17}$

Kemudian wawancara dengan Irman, salah satu nasabah BSM Area Jambi mengatakan: "Pihak BSM Area Jambi selalu memberikan saran-saran positif bagi pengembangan usaha saya seperti modal usaha yang ada jangan digunakan untuk kebutuhan konsumtif."18

Dalam menjalankan usahanya, modal merupakan modal awal bahkan dapat dikatakan sebagai penentu bagi usaha kecil dalam memilih jenis usaha dan menjalankan usaha yang sudah dipilihnya. Jumlah modal yang dibutuhkan oleh

\footnotetext{
${ }^{13}$ Wawancara, Irman, 26 Juli 2018

${ }^{14}$ Wawancara, Andrialdi, 26 Juli 2018

${ }^{15}$ Wawancara, Rini, 27 Juli 2018

${ }^{16}$ Wawancara, Andrialdi, 27 Juli 2018

${ }^{17}$ Wawancara, Rini, 27 Juli 2018

${ }^{18}$ Wawancara, Irman, 27 Juli 2018
} 
usaha kecil bervariasi tergantung dari jenis usahanya. Makin besar dan kompleks usahanya, maka semakin besar modal yang dibutuhkan.

\section{Rendahnya Nisbah Pembiayaan Usaha Kecil}

Beberapa permasalahan yang dihadapi oleh sektor usaha kecil kerakyatan seperti kekurangan modal, manajemen yang tidak rapi serta tingkat nisbah yang tidak menguntungkan pengusaha kecil sehingga tidak memungkinkan bagi usaha kecil untuk melakukan pinjaman karena diwajibkan juga adanya ketersediaan agunan dalam syarat peminjaman pembiayaan perbankan.

Wawancara dengan Andrialdi, Area Micro Banking Manager BSM Area Jambi bahwa: "Perbankan syariah selama ini sudah terbantu dengan pembiayaan mikro dengan nisbah yang rendah yaitu 18\% dan sangat membantu usaha kecil." 19 Berdasarkan hasil wawancara di atas dapat dipahami bahwa BSM Area Jambi sudah ada pembiayaan mikro dengan nisbah yang hanya $18 \%$.

\section{Mendorong Tertib Perizinan Usaha}

Membangun Usaha Mikro Kecil Menengah adalah salah satu wujud nyata dari pembangunan ekonomi berbasis kerakyatan. Didalam tatanan perekonomian Indonesia ekonomi kerakyatan merupakan kelompok pelaku ekonomi terbesar dan telah terbukti menjadi pengaman perekonomian nasional dimasa krisis serta menjadi dinamisator pertumbuhan ekonomi pasca krisis ekonomi. Paradigma pembangunan usaha kecil saat ini lebih mengarah pada upaya penciptaan kemandirian, partisipasi, daya inovasi dan kreativitas pelaku usaha kecil, dalam hal ini pemerintah berfungsi sebagai motivator dan fasilitator yang tujuannya adalah mencapai kemandirian, kematangan dan kedewasaan usaha kecil dalam menghadapi persaingan usaha yang semakin kompleks.

Kontribusi BSM Area Jambi sebagai fasilitator di bidang manajemen mengukur sejauh mana BSM Area Jambi memberikan bantuan teknis dalam bidang manajemen seperti pengurusan ijin usaha, pengurusan pembiayaan, pengelolaan SDM, pelatihan penggunaan IT, membuat manajemen usaha lebih baik dan membantu membuat rencana bisnis.

Hasil penelitian dengan Wati, salah satu nasabah BSM//pelaku usaha kecil Rumah Makan yang beralamat di Jl. Soemantri Brojonegoro Kota Jambi bahwa:

"BSM Area Jambi sudah ada mendorong kepada nasabah untuk membantu pengurusan izin usaha. Jika melihat harapan usaha kecil terhadap pemberdayaan ekonomi masyarakat ini, maka usaha kecil mengharapkan BSM Area Jambi dapat membantu melakukan pengurusan izin usaha juga. Pengurusan izin usaha yang dimaksud adalah pengurusan izin usaha dalam rangka pengembangan misalnya ijin BPOM dan sertifikat halal untuk makanan". ${ }^{20}$

Menurut Andrialdi, Area Micro Banking Manager BSM Area Jambi mengatakan bahwa: "Pihak bank dalam ketentuannya memang tidak menyaratkan

\footnotetext{
${ }^{19}$ Wawancara, Andrialdi, 31 Juli 2018

${ }^{20}$ Wawancara, Wati, 31 Juli 2018
} 
pengurusan izin usaha, hanya saja kami mendorong pihak nasabah untuk bisa mengurus izin usaha dan memberi tahu mekanisme pengurusannya supaya efektif. ${ }^{21}$

Berdasarkan wawancara di atas dapat diketahui bahwa BSM Area Jambi sudah ada mendorong kepada nasabah untuk membantu pengurusan ijin usaha. Jika melihat harapan usaha kecil terhadap pemberdayaan ekonomi masyarakat ini, maka usaha kecil mengharapkan BSM Area Jambi dapat membantu melakukan pengurusan izin usaha juga.

\section{Membantu Pemasaran bagi Produk-Produk}

Kontribusi BSM Area Jambi bagi usaha kecil sebagai fasilitator pada aspek pemasaran sangat merupakan peran yang dianggap penting oleh usaha kecil. Jaringan BSM Area Jambi yang luas serta variasi nasabah yang banyak memungkinkan BSM Area Jambi untuk menjadi fasilitator dalam aspek pemasaran. Menurut Andrialdi, Area Micro Banking Manager BSM Area Jambi bahwa:

"Bagi nasabah yang memiliki usaha dan sukses dengan usahanya yang juga meminjam di BSM, maka kami bantu pemasarannya melalui sepanduk, undangan temu nasabah dan lain sebagainya yang bisa memasarkan usahanya nasabah."22

Pengikutsertaan usaha kecil dalam pameran juga merupakan wujud kontribusi BSM Area Jambi sebagai fasilitator aspek pemasaran. Usaha kecil yang sering diikutsertakan dalam pameran, meskipun ada juga yang tidak pernah diikutsertakan. Seringkali usaha kecil senang untuk diikutsertakan dalam pameran, tetapi tidak terlalu sering karena alasan repot dan tidak ada karyawan. Meskipun demikian berdasarkan hasil penelitian, salah satu pelaku usaha kecil berharap sering diikutksertakan dalam pameran. Hal ini disebabkan karena pameran dapat dijadikan sebagai sarana memperkenalkan usaha dan produk kepada konsumen. Selain itu penghasilan yang diperoleh pada saat pameran kadang kala lebih besar. ${ }^{23}$

Selain mengikutsertakan dalam pameran, BSM Area Jambi juga dapat menjadi fasilitator dalam hal penyediaan tempat usaha. Hal ini dimungkinkan dengan adanya menggunakan dana CSR dari BSM Area Jambi atau kerjasama antara BSM Area Jambi dengan pengelola pasar atau kios.

\section{Faktor Pendukung dan Penghambat Kontribusi BSM Area Jambi}

Faktor pendukung dan penghambat kontribusi BSM dalam pembiayaan UMKM, khususnya usaha kecil di Kota Jambi adalah sebagai berikut:

\footnotetext{
${ }^{21}$ Wawancara, Andrialdi, 31 Juli 2018

${ }^{22}$ Wawancara, Andrialdi, 31 Juli 2018

${ }^{23}$ Observasi, 1 Agustus 2018
} 


\section{Faktor Pendukung}

Faktor agama. Agama (keyakinan atau religiusitas) berpengaruh terhadap minat nasabah bertransaksi. Keyakinan/religiusitas berpengaruh positif terhadap minat nasabah bertransaksi seperti yang dijelaskan oleh salah satu nasabah BSM yang mengatakan bahwa: Keyakinan atau pemahaman islami sangat mempengaruhi minat saya dalam mengajukan pembiayaan usaha kecil di BSM saat ini. Pemahaman prinsip-prinsip agama dan kehalalan jasa maupun produk menjadi pemicu utama untuk bertransaksi bagi saya. Keyakinan saya terhadap produk dan jasa yang baik dan halal akan membawa barokah dan manfaat yang baik. Terbebasnya dari unsur ribawi akan mempengaruhi juga minat saya bertransaksi, karena unsur ribawi dilarang oleh Islam. ${ }^{24}$ Berdasarkan wawancara di atas dapat diketahui bahwa agama (keyakinan/ religiusitas) berpengaruh bagi pilihan nasabah dalam pembiayaan usaha kecil di Kota Jambi.

Faktor pemerintah. Faktor pendukung kontribusi BSM dalam pembiayaan usaha kecil di Kota Jambi adalah kebijakan pembiayaan kepada masyarakat. Pembiayaan dengan nisbah yang tidak tinggi memudahkan pengusaha usaha kecil untuk mendapatkan pembiayaan tanpa direpotkan oleh penyediaan agunan. Pengusaha usaha kecil cukup menyediakan agunan senilai 30\% dari jumlah pembiayaan yang diberikan BSM. Bila seorang pengusaha usaha kecil membutuhkan modal sebesar Rp.100 juta, ia cukup menyiapkan agunan dengan nilai transaksi sebesar Rp. 30 juta. Sisanya akan dijamin oleh pemerintah. Selain itu, BSM Pembiayaan KUR selaras dengan syariah. Hal ini sangat dibutuhkan bagi pebisnis yang menginginkan implementasi syariah dalam segenap transaksinya.

Menurut Andrialdi, Area Micro Banking Manager BSM Area Jambi bahwa:

"Salah satu jenis pembiayaan yang diberikan BSM adalah pembiayaan mikro dengan limit pembiayaan hingga Rp.500 juta. Pembiayaan ini dapat dipergunakan untuk kebutuhan modal kerja ataupun investasi. Jangka waktu pembiayaan modal kerja hingga 3 tahun sedangkan untuk investasi hingga 5 tahun. Bagi pengusaha usaha kecil yang memiliki agunan terbatas, pembiayaan mikro merupakan solusi yang tepat." 25

Yang lebih menariknya dari kebijakan BSMS ini dalam upya memberikan bantuan dana kepada masyarakat kecil adalah terkait dengan pengelolaan bantuan pembiayaan itu sendiri harus dilakukan secara terbuka dan profesional dengan berprinsip dari, oleh dan untuk anggota. Dan juga dalam pelaksanaan programnya, berusaha memanfaatan kelompok-kelompok yang sudah ada di masyarakat sebagai sarana penyalur bantuan pembiayaan.

\section{Faktor Penghambat}

Faktor Karakter nasabah. Pelaksanaan proses pengendalian risiko harus digunakan bank untuk mengelola risiko tertentu, terutama yang dapat membahayakan kelangsungan usaha Bank. Pengendalian risiko dapat dilakukan oleh bank, antara

\footnotetext{
${ }^{24}$ Observasi, 1 Agustus 2018

${ }^{25}$ Wawancara, Andrialdi, 1 Agustus 2018
} 
lain dengan cara hedging, dan metode mitigasi risiko lainnya seperti penerbitan garansi, sekuritisasi aset dan credit derivatives, serta penambahan modal bank untuk menyerap potensi kerugian. Faktor-faktor yang menjadi aspek penilaian kelayakan suatu pembiayaan pada BSM Area Jambi menurut Andrialdi, Area Micro Banking Manager BSM Area Jambi bahwa: "Faktor yang mempengaruhi kontribusi BSM dalam pembiayaan usaha kecil di Kota Jambi adalah tingkat pengembalian pinjaman dalam bentuk angsuran yang terkadang tidak lancar, meskipun presentasenya kecil sejak 2010-2017."26

Masih wawancara dengan Andrialdi, Area Micro Banking Manager BSM Area Jambi bahwa:

"Nasabah yang terlambat membayar kewajiban dari jadwal yang telah ditetapkan, maka bank berdasarkan kesepakatan yang telah dibuat sebelum akad, membebankan dan nasabah setuju membayar denda ( $t a{ }^{\prime} d z i r$ ) atas keterlambatan pembayaran. Dana dari denda yang diterima oleh bank akan diperuntukkan sebagai dana sosial atau untuk kemaslahatan umat, dalam hal ini adalah masuk pada qardhul hasan yang memuat perangkat keras (hardware), perangkat lunak (software), data base, parameter, tahapan proses, asumsi yang digunakan, sumber data, dan output yang dihasilkan sehingga memudahkan pengendalianmelekat (built-in controls) dan pelaksanaan jejak audit (audit trail)."27

Nasabah tidak melaksanakan kewajiban pembayaran/pelunasan kewajiban tepat pada waktu yang diperjanjikan sesuai dengan tanggal jatuh tempo atau jadwal angsuran yang ditetapkan dalam Surat Sanggup Membayar yang telah diserahkan nasabah kepada bank. Wawancara dengan Andrialdi, Area Micro Banking Manager BSM Area Jambi bahwa:

"Di mana faktor character menjadi prioritas di antara berbagai faktor tersebut yang bila aspek yang pertama tersebut tidak terpenuhi maka faktor yang lainnya tidak diperhitungkan. Faktor Collateral juga merupakan faktor yang sangat mempengaruhi disetujuinya suatu pembiayaan mengingat pada BSM Area Jambi pembiayaan murabahah lebih dominan. Dalam menentukan nilai pembiayaan nilai jaminan menjadi faktor penentu, yana mana nilai pembiayaan ditentukan berdasarkan nilai jaminan yang dimiliki nasabah. Selama ini NPF atau nasabah yang menunggak setiap bulan kecil dan masih bisa diteloransi." 28

Mengatasi nasabah yang tidak beritikad baik dalam menyelesaikan kewajibannya. Sering dijumpai kendala dimana nasabah yang tidak beritikad baik dalam menyelesaikan kewajibannya. Hal demikian mengakibatkan jalinan komunikasi antara nasabah dengan bank menjadi putus atau tidak terjalin dengan baik. Apabila tidak dapat dihubungi melalui pesawat telepon atau bisa dihubungi

\footnotetext{
${ }^{26}$ Wawancara, Andrialdi, 7 Agustus 2018

${ }^{27}$ Wawancara, Andrialdi, 7 Agustus 2018

${ }^{28}$ Wawancara, Andrialdi, 14 Agustus 2018
} 
tetapi peringatan harian ini tidak ditindak lanjuti dengan itikad baik oleh nasabah maka pihak bank akan mendatangi kediaman nasabah tersebut untuk mengingatkan atas kewajiban yang menunggak tersebut serta mencari jalan keluar agar pihak nasabah dapat mengembalikan kewajibannya yang telah jatuh tempo. ${ }^{29}$

Apabila hal tersebut tidak ditindak lanjuti oleh nasabah dengan itikad baik maka pihak bank akan memberikan surat peringatan yang tujuannya untuk mengingatkan agar nasabah segera menyelesaikan tunggakannya yang telah jatuh tempo. Dimana surat peringatan ini ditujukan kepada nasabah yang menunggak disertai dengan tembusan kepada KPKNL (Kantor Pelayanan Kekayaan Negara dan Lelang). Penerbitan surat peringatan ini maksimal sebanyak tiga kali, namum jika nasabah tetap tidak menanggapi, maka tindakan yang diambil oleh BSM Area Jambi mengajukan Somasi melalui Pengadilan Negeri. ${ }^{30}$

Penerbitan somasi ini diperuntukkan bagi nasabah yang benar-benar tidak mempunyai itikad baik dalam memenuhi kewajibannya. Somasi merupakan surat peringatan atas perintah yang disampaikan oleh Hakim kepada nasabah untuk segera memenuhi kewajibannya yang belum ia tunaikan. Somasi cukup efektif untuk memberikan gertakan kepada nasabah dalam pembiayaan murabahah, sehingga mereka bersedia melanjutkan menyelesaikan masalahnya itu melalui restrukturisasi.

Faktor Dokumen. Faktor yang mempengaruhi kontribusi BSM dalam pembiayaan usaha kecil di Kota Jambi adalah keabsahan dokumen yang dimiliki calon nasabah. Wawancara dengan Andrialdi, Area Micro Banking Manager BSM Area Jambi yaitu:

"Dokumen atau keterangan yang dimasukkan atau disuruh masukkan ke dalam dokumen yang diserahkan oleh nasabah kepada bank sebagaimana dimaksud dalam pengakuan dan pembebasan bank dari tuntutan/gugatan pihak ketiga dalam perjanjian ini palsu, tidak sah, atau tidak benar." 31

Bank harus menyeleksi dokumen nasabah pembiayaan (wirausahawan), setelah itu bank syariah memberikan modal untuk pembiayaan kepada para wirausahawan yang telah lolos seleksi, baik tempat, laporan keuangan, jaminan dan sebagainya.

Setelah nasabah mendapatkan modal pembiayan, BSM Area Jambi saat ini tidak lepas tangan begitu saja, bank syariah harus melakukan pembinaan agar nasabah yang telah diberikan pembiayaan tidak salah langkah dalam menjakan usahanya.

\section{Penutup}

Berdasarkan pemaparan hasil penelitian di atas, maka dapat disimpulkan sebagai berikut: pertama, kontribusi BSM Area Jambi dalam pembiayaan UMKM di Kota Jambi terus meningkatkan setiap tahunnya selalu ada inovasi dari BSM untuk membantu pertumbuhan dan perkembangan usaha UMKM. Sebelumnya BSM menfokuskan pada pemberian modal usaha saja. Namun saat ini, BSM Area Jambi

\footnotetext{
${ }^{29}$ Observasi, 14 Agustus 2018

${ }^{30}$ Observasi, 14 Agustus 2018

${ }^{31}$ Wawancara, Andrialdi, 14 Agustus 2018
} 
sudah berperan aktif dalam memberikan pendampingan usaha seperti mengurus izin usaha bagi usaha yang belum memiliki izin resmi dari pemerintah, membantu promosi dan memberikan konsultasi mengenai pengembangan usaha dan menfasilitasi keberadaan tempat usaha dan memberikan pelatihan pengelolaan keuangan. Kedua, faktor yang mendukung kontribusi BSM dalam pembiayaan UMKM di Kota Jambi adalah agama penganut mendukung UMKM memilih pembiayaan BSM dan kebijakan pemerintah dalam bentuk KUR sebagai pembiayaan yang meringankan bagi UMKM. Sedangkan penghambatnya dari sisi nasabah adalah kesulitan menilai UMKM yang feasible dan bankable yang memenuhi persyaratan bank, akses informasi yang terbatasi kepada UMKM mengenai fasilitas pembiayaan yang ada menyebabkan rendah animo masyarakat terhadap fasilitas pembiayaan BSM dan kesulitan membina manajemen UMKM seperti pemisahan keuangan antara keuangan pribadi dengan usaha.

\section{BIBLIOGRAFI}

Adiwarman Karim, Bank Islam Analisis Fiqih dan Keuangan, Jakarta: RajaGrafindo, 2004.

Anonim, Kamus Bahasa Indonesia, Jakarta: Pusat Bahasa Departemen Pendidikan Nasional, 2008.

Dini Arwati, Peran Strategis Ekonomi Berbasis Syariah Dalam Pemberdayaan Ekonomi Sektor Usaha Mikro, Kecil dan Menengah (UMKM) Ditinjau Dari Penerapan Akuntansi Syariah dengan Akuntansi UMKM, (Jurnal Ekono Insentif Kopwil 4 Volume 4 No. 1 Juli 2010.

Eko Kurniasih Pratiwi \& Nasitotul Jannah, Peran Perbankan Syariah terhadap Pengembangan UMKM di Kota Magelang, Jurnal FAI Universitas Muhammadiyah Magelang, 2014.

Hana Zunia Rini, Peran Perbankan Syariah terhadap Eksistensi UMKM, Jurnal Academica- Vol. 1 No. 1, Januari - Juni 2017.

Hafidh Munawir, Perencanaan Strategi Pengembangan Bank Syariah di Indonesia, Jurnal Ilmiah Teknik Industri Vol. 4 No. 1 Agustus 2005.

Ismail, Perbankan Syariah, (Jakarta: Kencana, 2011. , Manajemen Perbankan, Jakarta: Kencana, 2013.

Jaka Sriyana, Strategi Pengembangan Usaha Kecil dan Menengah (UKM), Yogyakarta: Universitas Islam Indonesia, 2010.

Matthew B. Miles dan A. Michael Huberman, Analisis Data Kualitatif, Terj. Tjetjep Rohedi Rohidi, Jakarta: UI Press, 2007.

Muhammad Syafi'i Antonio, Bank Syariah dari Teori ke Praktik, Jakarta: gema Insani, 2001.

Muhammad, Teknik Perhitungan Bagi Hasil dan Profit Margin pada Bank Syariah, Yogyakarta: UII Press, 2006. 
Mukhtar, Bimbingan Tulisan, Tesis dan Artikel Ilmiah, Jambi: Sulthan Thaha Press, 2007.

Musa Hubeis, Prospek Usaha Kecil dalam Wadah Inkubator Bisnis, Bogor: Ghalia Indonesia, 2011.

Muslimin Kara, Konstribusi Pembiayaan Perbankan Syariah Terhadap Pengembangan Usaha Mikro Kecil dan Menengah (UMKM) di Kota Makassar, Asy-Syir'ah, Jurnal Ilmu Syari'ah dan Hukum Vol. 47, No. 1, Juni 2013.

Ridwan, Dasar-Dasar Statistik, Bandung: Al-Fabeta, 2003.

Rizqi Fithriah Cantika, Pembiayaan Syariah dalam Pengembangan Industri Kreatif. Jurnal Mahasiswa S1 Ekonomi Syariah Universitas Airlangga Surabaya.

Tim Penyusun, Pedoman Penulisan Tulisan (Edisi Revisi), Jambi: Fakultas Syariah IAIN STS Jambi dan Syariah Press, 2012.Suharsimi Arikunto, Prosedur Penelitian, Jakarta: Rineka Cipta, 2006. , Manajemen Penelitian, Jakarta: Rineka Cipta, 2010.

T. Guritno, Kamus Besar Bahasa Indonesia dan Kamus Ekonomi, Jakarta: 1992, Cet: II.

Taqiyudin Nabhani, Membagun Sistem Ekonomi, Surabaya: Risalah Gusti, 1996.

Tulus Tambunan, Usaha Mikro Kecil dan Menengah di Indonesia: isu-Isu Penting, Jakarta: LP3ES, 2012.

Undang-undang Nomor 21 tahun 2008 tentang Perbankan Syariah

Undang- Undang Nomor 20 Tahun 2008 tentang Usaha Mikro, Kecil dan Menengah (UMKM)

Usman Rianse, dkk., Peran Pemerintah dan Perguruan Tinggi dalam Pengembangan Ekonomi Kreatif Berbasis Budaya Lokal, (Kongres Kebudayaan Indonesia (KKI) Tahun 2013, Yogyakarta 8-11 Oktober 2013.

Yustinus Prastowo, dkk., Ketimpangan Pembangunan Indonesia dari Berbagai Aspek, Jakarta: INFID, 2014. 